\title{
IMPACT OF INTERNET ADVERTISING ON CHILDREN AND YOUTH AND ASSESSMENT OF ITS SOCIAL EFFECTS
}

\section{IZABELA OSTROWSKA}

University of Szczecin, Faculty of Management and Economics of Services, POLAND

e-mail: izabela.ostrowska@wzieu.pl

\begin{abstract}
RECEIVED
6 November 2018

ACCEPTED

3 December 2018

JEL

CLASSIFICATION

M37, M38

KEYWORDS

marketing, advertising, young consumers

ABSTRACT Children are an attractive target group for companies, not only because of the financial resources they have, but also due to the impact they have on their parents when making purchasing decisions. For these reasons, a wide range of marketing communication activities is addressed to them through various media. The main goal of the article is to analyze the extent of Internet use by children and to assess the impact of online advertising on young audience. The Internet as a modern communication channel creates the possibility of affecting children through many stimuli and in different ways. Polish and European legislation tries to protect the youngest consumers from exploiting their ignorance and naivety, however, online advertising is more difficult to control than, for example, a TV commercial.
\end{abstract}

\section{Introduction}

Children are an attractive target group for companies and for this reason they are subjected to wide range of marketing communication activities in various media. Marketing communication can be understood as the transmission of information between various market players that concern a company, product brand or other aspects of marketing activities undertaken (Bajdak, 2013, p. 44). Marketing communication tools that allow to 
influence consumer behavior include: personal sales, advertising, public relations, informal communication, sales promotions, sponsorship (Wiktor, 2013, pp. 7-8). The article will focus on advertising activities that are broadcast on the internet. This modern communication channel creates the possibility of affecting children in an attractive way and is assessed positively by them. The main goal of the article is to analyze the scope of Internet use by children and to assess the impact of online advertising on young audiences.

In 2015, the population of Poland amounted to 38.5 million people, of which 6.9 million were children (up to 18 years of age), i.e. $5.5 \%$. In the literature, the most active consumers are children above 9 years of age and this group according to the Central Statistical Office data includes 2.9 million people (CSO, 2016b, p. 136). Based on a CSO report on household spending, it can be stated that spending on pocket money 1 is on average $1.7 \%$ of expenditure per person in a Polish household, which is 17.67 PLN per person (CSO, 2016a, p. 47). In the entire Polish population, taking into account the size of the children and youth segment up to the age of 18, pocket money is almost PLN 122 million per month. For this reason, it is a market segment that is of interest to companies.

\section{Children and adolescents as recipients of advertising}

From the point of view of children, multimedia ads are a very attractive message. Considering their construction, they are usually short films, full of attractive images, containing a simple and understandable message, cheerful mood and pleasant music. They often present favorite heroes of children known from fairy tales, small animals or families with children. The youngest recipient identifies with children appearing in advertisements, which are presented as role models. Presenting the advertised goods, they convince the young recipient to buy them. The child wants to own the advertised products in order to be like his peers from commercials (Doliński, 2003, p. 155; Łaciak, 2003, p. 159).

By their very nature, advertisements only display the advantages of the product, thus distorting the reality. It should be noted that the characteristic feature of a small child as a recipient of messages is often a lack of critical thinking and credulity. Children, to believe in the message addressed to them, do not require rational justification, but they are guided by emotions. Meanwhile, advertising can also present a false image of reality using incomplete and distorted information (Braun-Gałkowska, 1997, p. 20). The persuasive message addressed to young audiences often uses manipulation techniques, such as: fragmentation of reality or inducement to make immediate decisions, without time to think about them. For this reason, advertising message may pose a threat to young people and lead them to make wrong decisions or contribute to the feeling of frustration or low self-esteem resulting from unrealized needs. As W. Smyl emphasizes, advertisements propagate products, but also a specific way of life, passing values, views and behavioral patterns (Smyl, 2009, p. 212).

It should be analyzed for what reason ads targeted at children are more and more often negatively perceived by parents and the environment of psychologists and pedagogues (Halińska, 2013; Wiktor, 2013; Wiśniewska, 2015; Waluś, 2017). The basic task of advertising is to convince people to use a specific offer (service or product) and to provide recipients with information about this offer. Children are characterized by: inability to separate scenarios from real states, easy submission to idols (specific for a given age group), unchecked criticism in perceiving reality, unspecified criteria of values, emotional immaturity, lack of life experience, and inability to assess the level of threat and risk. A child, up to the age of seven, is often unable to properly assess the real value of the product being advertised (Olszewski, 2008, pp. 224-232; Bates Ames, Baker, 2018, p. 220). The younger child does not understand the purpose of advertising, and consequently easily succumbs to them (Budzyński, 2000, p. 15). It is 
only at school age that children begin to understand what the purpose of advertising is and get a greater distance from promotional content (Wiśniewska, 2015, pp. 30-32; Grzybczyk 2004, pp. 64-65). It should be emphasized that advertisements influence not only consumer decisions, which is their main goal, but also shape the attitudes of the child towards life and its relationships with other people (Bromboszcz, 1993, pp. 60-61).

The child co-decides on family shopping, often having a dominant influence on the consumer choices of adult family members. Kossowski's research indicates that $90 \%$ of pre-schoolers ask their parents to buy products viewed in advertisements (for Maksymiuk, Jasielska, 2010, p. 9). Lindstorm's research has shown that in every second family, parents take into account the teenager's opinion, choosing products such as: a car, a clothing, a mobile phone (Lindstorm, 2005). From the "Kids' Power" research carried out by the IQS research agency in 2016, it appears that children more and more often make purchasing decisions like adults. Almost half (49.4\%) of the surveyed women admitted that their children influence the selection of accessories for interior decoration, codecide on the location of holiday recreation $(41.9 \%)$, the purchase of furniture $(34.6 \%)$ or the choice of a restaurant for family lunch (13\%) (Online 1).

Research shows that advertising increases the demand for unhealthy products, such as sweets, fast foods, dietary supplements or highly processed foods (Kułaga, Barwicka, 2008, pp. 121-125). They cause children and teenagers to dream about having the products being advertised, and in their choices, they are guided primarily by the brand of the product, not its functionality and irrationally spend the money. Advertisements targeted at children strongly influence awareness, needs and preferences, as well as market behavior of young consumers who are just learning how to act and what is really good and what is bad for them (Ostrowska, 2017).

The child often forces the shopping of advertised goods by crying, screaming or unruly behavior (Jachnis, Terelak, 1998, 295-296, Ryłko-Kurpiewska, 2004, p. 14). When parents cannot or do not want to succumb to the child's requests to buy the advertised product, it can trigger discussions and conflicts in the family. Thus, the advertisements enter into the relations of the child and parents, and consequently cause a sense of incomprehension and weaken the psychic bond between them (Kossowski, 1997).

\section{Advertising in the Internet}

Children are exposed to the impact of advertising in various media and places. Polish market offer includes radio and television thematic channels for children, newspapers with their favorite heroes, and various advertising activities are also carried out on the Internet. What distinguishes this last medium? The Internet is filled with ads related to the content being viewed. Tools such as Google Ads are used, with the help of which the content of the page being browsed is analyzed and on this basis ads matching the interests of the user are selected. Google also offers companies a service that increases the chance of returning to the site, that is, displaying ads to stores or specific items that they have browsed, but have not bought them.

Popular social networks offer manufacturers boxes for personalized advertising, young people are redirected to websites with offered products or to company profiles whose main task is to establish relationships with Internet users. On the Internet, companies also prepare websites offering advertising-games (the so-called advertainment), in which the brand is exposed during the game or solving quizzes by participants. These types of advertising activities are more effective than television commercials, which often interrupt the viewer's other activities and are therefore negatively perceived. In addition, on the Internet, a young person seeking entertainment, reaching an attractive website, initiates contact with the brand (Jasielska, Maksymiuk, 2010, p. 63). Many of these promotional 
activities are not perceived by children as a way of persuading to buy, but rather as a selfless supply of information or entertainment. At the same time, such contact with the brand and a long-lasting relationship strongly affect the cognitive sphere of a young consumer who prefers brand-name advertising when shopping.

As rightly observed by Łęgowski, the phases of consumer behavior on the market are noticeable. Common elements can be found in many different perspectives of the consumer's behavior process: identification (awareness) of the need, seeking information, evaluation of possibilities (alternatives), purchase decision, after-sales procedure (consumption of a certain value) (Łęgowski, 2017, p. 95). In the Internet, this process can proceed in a virtual and simplified way. When the consumer sees the advertisement, it realizes the desire to have a product, and the click in the ad slot moves the consumer to the store's website, where it can finalize the transaction. Some buyers will not leave the search phase, i.e. they will check the offers of other companies on the internet, but some of them may choose a more simplified procedure, especially if the advertisement was convincing. Internet shopping through its virtual character encourages greater carelessness in spending money, and additionally secured by the possibility of easy returns within 14 days, is a factor strengthening this approach. Especially young people like to buy through the Internet and feel less worries about virtual shopping than mature consumers(Jaciow, Wolny, 2011, s. 64).

Polish and European legislation tries to protect the youngest consumers from taking advantage of their ignorance and naivety. So far, there has not been one act regulating the issue of advertising in a holistic way. Regulations, due to their diverse nature, are placed in various acts (the Act on radio and television, the Pharmaceutical Law act, the Act on competition and consumer protection of 16 February 2007, the Act of 16 April 1993 on combating unfair competition or the European Convention on Transfrontier Television) (Olszewski, 2008, p. 224). Internet advertising is more difficult to regulate than, for example, a TV commercial.

\section{Children and youth in the Internet}

The environment of children and adolescents is dominated by smartphones and computers which fill time for play, learning, entertainment or sleep of earlier and earlier children. On the Internet, children spend more and more time, also staying outside the home, because they use cell phones to enter the network. Growing up of children takes place more and more in the virtual world, often beyond the control of parents or guardians, and direct contacts with peers are replaced by conversations on social networks (Wiśniewska, 2015, p. 32).

The research shows that laptops, smartphones or tablets users are already very young (2 or 3 yearolds), and these devices are more attractive to children than traditional blocks or board games. (Waluś, 2017b, p. 55). At the same time, it should be noted that parents themselves are introducing children into the world of new media. American research shows that $65 \%$ of parents use mobile devices to calm a child, $60 \%$ use it to entertain kids, e.g. when shopping, and $29 \%$ use to put young children to sleep (Online 2). In Poland, over $40 \%$ of children before the second year of life use mobile devices, and nearly $30 \%$ of children in this age use them every day, so Internet users are younger and younger (Goetz, 2016, p. 23).

The report of the Center for Social Prevention shows that almost all junior high school students use computers and smartphones $-98 \%$ of them use a computer every day, and $89 \%$ use the phone (Digital children, p. 135). Most young people are active on social networks and online forums, where the greater part of social life takes place. These media became for them the basic form of communication, spending free time and making friends (Waluś, 2017, p. 68). 98\% of teenagers and $42 \%$ of younger children have an account on Facebook (Zawadka, 2017, p. 1). You can observe different preferences regarding belonging to a virtual community depending on the age of the 
child, i.e. primary school students choose Snapchat, high school students prefer Instagram. Every third day, every day, one or more images are added to the web, and every tenth to dozens of photos a day (Święchowicz, 2017, p. 31). It is common opinion among young people that life without Internet would be boring, empty and meaningless. This opinion was expressed by $58 \%$ of respondents (CBOS, 2016, p. 184).

Pedagogical standards, which determine the amount of time devoted to the perception of multimedia messages does not interfere with the proper development of the child, indicate a maximum of two and a half hours in front of the screen daily (the younger the child, the shorter the time should be). The number of hours that exceeds this norm is not without influence on psychological and social development (Izdebska, 2000; cf Smyl, 2009, p. 131). Meanwhile, according to carers, young people (from 6 to 19 years old) spend on the internet on average almost 15 hours a week. As many as $36 \%$ of respondents declared that their children spend more than 15 hours per week in the network. In the opinion of nearly half of the respondents (49\%), children spend the right amount of time on the Internet. Over two fifths (43\%) - slightly more than seven years ago - think, however, that their charges are staying online for too long (CBOS, 2015, pp. 2-3). It is worth mentioning that these people can also watch TV, so the time spent in front of the screen exceeds the norm defined by pedagogues as safe for the development of a young person.

\section{The role of parents and education}

Promotional activities of companies are an inseparable element of the free market. J. Wiktor rightly notes that advertising message is often a specific form of a lie, because it deprives the addressee of a comprehensive, true knowledge of the subject of the offer, causes serious consequences in the emotional life of a human being, and as a result causes moral harm to the recipient (Wiktor, 2013, p. 197). Council Directive EU 89/552/EEC Art. 16 in a special way protects minors against potential moral and physical damage that television advertising may cause. The Act on Counteracting Dishonest Market Practices contains a ban on placing in the advertisement a direct appeal of children to purchase advertised products or to persuade parents or other adults to buy them the advertised products (Act of 23 August 2007..., art. 9 p. 5). In the radio and television broadcasting regulations it is permissible to interrupt programs with commercials, but with the exception of programs addressed to children (Act of 29. 12. 1992..., art. 16a.) In Polish law, so-called product placement in television programs is allowed, however, children's programs are excluded from the scope of permissible use (The Act of December 29, 1992, art. 17a). Children are protected by Polish and European regulations due to their credulity and susceptibility to persuasive messages addressed to them in advertising (Ostrowska, 2017). However, such protection of young recipients by legislation does not apply to advertisements placed on the website. Meanwhile, the EU Kids Online survey results are worrying, as many as 39\% of children aged 11-16 admitted that they cannot change privacy settings on a social networking site (it is worth noting that this is one of the basic conditions for privacy protection on the web), $42 \%$ said that they cannot block unwanted contacts on the communicator, and as many as $70 \%$ did not know how to block objectionable advertisements (Livingstone, Haddon, 2009, p. 10).

Parental control and a rational approach to the use of new media by children, especially at an appropriate and limited time, can contribute to protecting children from the negative effects of Internet addiction and excessive exposure to advertising messages. As $\mathrm{S}$. Waluś emphasizes, many parents are unaware of the risks and are even satisfied that the child is occupied with a tablet or smartphone for several hours. The problem is also aggravated by the behavior of parents themselves, who use new media compulsively and their behavior is imitated by children 
(Walenty, 2017b, pp. 61-63). Many parents cannot cope with this problem because they cannot control the content they are browsing or restrict the time the child spends on the web. On average, Polish mothers dedicate 7 minutes less to their children than European women, who spend 74 minutes on this daily basis. On average, the Polish father has only 15 minutes for children during the day (Halińska, 2013, p. 40). Parents are also not supported by schools. The results of the audit carried out by the Supreme Audit Office (NIK) in 2016 in schools, counseling centers and other facilities indicate that schools downplay the problem of Internet addiction or do not notice it at all, despite the fact that parents, teachers, pedagogues and psychologists inform about the threats (for Waluś, 2017, p. 69).

\section{Conclusions}

Children and youth require special protection against excessive exposure to promotional activities. Market inexperience and credulity may cause them to be exposed to unreasonable decisions under the influence of advertisements. The ads have important advantages for young consumers, such as providing information about products, their functions, availability, price or providing entertainment. However, these promotional activities may cause risks in the form of inferiority sense due to the inability to buy advertised products, give rise to unnecessary competition with peers, cause excessive spending on advertised brands and thus financial problems, as well as cause conflicts in the family.

The young consumers are a large market segment, which is why many companies address advertising messages to them. Ads targeted at children are visually appealing, they promise benefits and pleasures associated with the purchase. Children spend more and more time in the Internet, where the limitation of the number of ads displayed and the type of advertising is difficult to control through legislation. For this reason, one can notice the need to educate young recipients about the purpose of advertising and how to protect their privacy, as well as the possibilities of blocking promotional messages by means of special programs. The easiest way to protect children from excessive exposure to advertising is to limit the amount of time spent online, and here the role of parents and school is noticeable. On weekdays, a large part of the day is spent by young people in schools, hence prohibiting the use of mobiles has been introduced in many educational institutions. IT education should also include aspects of protecting one's personal data and limiting the number of presented ads.

Parents have the greatest opportunity to protect children and young people against excessive exposure to advertising. They should realize that the younger their child is, the more difficult it is to defend it against all kinds of persuasive messages. Parents can install programs that will partially reduce the number of ads, and above all, reduce the time spent by children in front of the screen. This will have a positive impact on the child's emotional and intellectual development, but it can also positively affect the improvement of family relationships.

\section{References}

Bajdak, A. (2013). Komunikacja marketingowa przedsiębiorstw a budowanie relacji z podmiotami otoczenia na rynkach zagranicznych. Studia Ekonomiczne. Zeszyty Naukowe Uniwersytetu Ekonomicznego w Katowicach, 140, 42-56.

Bates Ames, L., Baker, S.M. (2018). Rozwój psychiczny dziecka od 0 do 10 lat. Gdańsk: Gdańskie Wydawnictwo Psychologiczne.

Braun-Gałkowska, M. (1997). Reklama telewizyjna a dzieci. Edukacja i Dialog, 5, 15-20.

Bromboszcz, E. (1993). Percepcja reklamy telewizyjnej przez dzieci. Psychologia Wychowawcza, 160-66.

Budzyński, W. (2000). Reklama. Techniki skutecznej perswazji. Warszawa: Poltext.

CBOS (2015). Dzieci i młodzież w internecie - korzystanie i zagrożenia z perspektywy opiekunów. Warszawa: Centrum Badania Opinii Społecznej. 
CBOS (2016). Raport Młodzież. Warszawa: Centrum Badania Opinii Społecznej..

Coraz młodsze dzieci korzystają ze smartfonów... nawet niemowlęta (2015). Retrieved from: https://technologie.onet.pl/coraz-mlodszedzieci-korzystaja-ze-smartfonow-nawet-niemowleta/81yqcdt (3.10.2018).

Doliński, D. (2003). Psychologiczne mechanizmy reklamy. Gdańsk: Gdańskie Wydawnictwo Psychologiczne.

Goetz, M. (2016). Mózg stabletyzowany. Głos Nauczycielski, 12-13, 23.

Grzybczyk, K. (2004). Prawo reklamy. Zakamycze: Kantor Wydawniczy Zakamycze.

GUS (2016b). Rocznik demograficzny 2016. Warszawa.

Halińska, M. (2013). Tablety na święty spokój. Charaktery, 6, 40-43.

Izdebska, J. (2000). Rola mass mediów w kształtowaniu przez dziecko obrazu świata. In: W. Strykowski (ed.), Media a edukacja. Poznań: Wydawnictwo eMPi.

Jachnis, A., Terelak, J.F. (1998). Psychologia konsumenta i reklamy. Bydgoszcz: Oficyna Wydawnicza Branta.

Jaciow M., Wolny R. (2011), Polski e-konsument. Typologia, zachowania. Gliwice: Helion.

Jasielska, A., Maksymiuk, R.A. (2010). Dorośli reklamuja, dzieci kupują. Kindermarketing i psychologia. Warszawa: Scholar.

Kossowski, P. (1997). Reklama i dziecko. Pedagogiczny wymiar zjawiska. Problemy Opiekuńczo-Wychowawcze, 8, 9-12.

Kułaga, Z., Barwicka, K. (2008). Reklama środowiskiem dziecka - przegląd badań i danych dotyczących wpływu reklamy na zdrowie dziecka. Problemy Higieniczno-Epidemiologiczne, 89, 120-127.

Łaciak, B. (2003). Wizerunek dziecka w reklamie telewizyjnej. In: B. Łaciak (ed.), Dziecko we współczesnej kulturze medialnej. Warszawa: Instytut Spraw Publicznych.

Łęgowski, Sz. (2017). Budowanie relacji z klientem jako determinanta lojalności i satysfakcji konsumenta na rynku telefonii komórkowej. Studia Ekonomiczne. Zeszyty Naukowe Uniwersytetu Ekonomicznego w Katowicach, 328, 93-105.

Lindstorm, M. (2005). Dziecko reklamy. Warszawa: Świat Książki.

Livingstone, S., Haddon, L. (2009). EU Kids Online: Final Report. London.

Olszewski, B. (2008). Uwagi o reklamie adresowanej do dzieci. Przegląd Prawa i Administracji, 77, 223-235.

Ostrowska, I. (2017). Etyczne aspekty promocji adresowanych do dzieci. Studia Ekonomiczne, 328, 83-92.

Ryłko-Kurpiewska, A. (2004). Dziecko - odbiorca traktowany instrumentalnie. Marketing w Praktyce, 8, 11-14.

Sklep // "kids'power" - świat dzieci 3-16 (2018). Retrieved from: www.grupaiqs.pl/sklep/kids-power-swiat-dzieci-3-16.

Smyl, W. (2009). Etyczna ocena reklam dziecięcych. Media, Kultura, Społeczeństwo, 1 (4), 121-146.

Święchowicz, M. (2017). Być w z@sięgu. Newsweek, 24, 31-32.

Waluś, S. (2017). Bezpieczeństwo dzieci w Internecie. In: K. Pujer (ed.), Humanistyka i nauki społeczne doświadczenia konteksty wyzwania, tom 1. Wrocław: Exante.

Waluś, S. (2017b). Wychowanie do korzystania z nowych mediów. In: K. Pujer (ed.), Humanistyka i nauki społeczne doświadczenia konteksty wyzwania, tom 1. Wrocław: Exante.

Wiktor, J.W. (2013). Komunikacja marketingowa. Modele, struktury, formy przekazu. Warszawa: PWE.

Wiśniewska, L.A. (2015). Myszka i co dalej? Szanse i zagrożenia z dorastaniem online. In: M. Banasiak, A. Wołowska (eds.), Szkoło, jaka jesteś? Problemy nauczycieli i uczniów we współczesnej szkole. Warszawa: Difin.

Zawadka, G. (2017). Nasze dzieci toną w sieci. Rzeczpospolita, $182,1$.

Cite this article aS: Ostrowska, I. (2018). Impact of internet advertising on children and youth and assessment of its social effects. European Journal of Service Management, 4 (28/1), 239-245. DOI: 10.18276/ejsm.2018.28/1-30. 